\title{
SHARIA BANKING TOWARDS SUSTAINABLE FINANCE IN PALM OIL INDUSTRY
}

\author{
Eko Tama Putra Saratian ${ }^{1 *}$, Harefan Arief ${ }^{1}$ \\ ${ }^{1}$ Faculty of Economics and Business, Mercu Buana University \\ *eko.tama@mercubuana.ac.id
}

\begin{abstract}
This study aims to analyze the application of sustainable finance principle in the palm oil industry financing that stipulated by the Financial Services Authority as banking regulator. Sharia Bank $\mathrm{X}$ is a member of the First Mover Bank set by the Regulator on the Sustainable Finance project. The identification of the problem in this research is the environmental issues caused by the utilization of oil palm land that does not pay attention to the environmental good governance, so the Regulator involves banks in making policy on sustainable financing of palm oil industry. Design in this research is qualitative approach, with purposive sampling method. Data analysis was conducted by Focus Group Discussion (FGD) from internal and external Sharia Bank X. The result of research showed that in applying the principle of sustainable finance, Sharia Bank X has set acceptance criteria which contains the aspects of Environment, Social and Governance (ESG) in the fund distribution to companies engaged in the field of palm oil.
\end{abstract}

Keywords: Green banking, palm oil industry, sharia banking, sustainable finance

\section{INTRODUCTION}

Indonesia has an important role because it is one of the countries with the largest forests in the world. Indonesia's tropical rainforest is in the third rank (after Brazil and Zaire) in the largest biodiversity as well as the largest rainforest in Asia. Indonesia's forests as the world's lungs are expected to contribute to the reduction of greenhouse gas emissions. At the national level, forests play a role as national development capital and are expected to have tangible benefits for the lives and livelihoods of the Indonesian people, both in a balanced and dynamic ecological, socio-cultural and economic benefits.

The forests' role for Indonesia is increasingly important because half of Indonesia's territory is covered by forests. Based on data from the Ministry of Environment and Forestry, Indonesia's forest cover in April 2018 covers 125.9 million Ha or 63.7\% of Indonesia's land area. One of the potential agricultural sub-sectors is plantation. The contribution of the agricultural sector to the Gross Domestic Product (GDP) is around $13.96 \%$ in the third quarter of 2017, so that the agricultural sector is one of the second largest GDP contributors after the processing industry. The biggest contributor to the agricultural sector is dominated by the plantation sub-sector. The largest plantation production in Indonesia is palm oil, and Indonesia is the world's largest palm oil exporter. The production of Crude Palm Oil (CPO) in 2017 reached 38.17 million tons and Palm Kernel Oil (PKO) 3.05 million tons, so the total of Indonesian palm oil in 2017 was 41.98 million tons. This figure shows an increase in production by $18 \%$ compared to 2016 production of 35.57 million tons, which consists of CPO of 32.52 million tons and PKO of 3.05 million tons.

According to the news quoted from www.tuk.or.id, although palm oil derivatives provide a significant export contribution and become one of the largest contributors to the country's income, frequently the land clearing of palm oil plantations are not followed by attention to environmental and social aspects, including community rights, so that this industry is filled with problems and challenges. On the social side, according to news quoted from www.mongabay.co.id, the Indonesian Forum for the Environment that called as Walhi stated that there had been an imbalance domination in the natural resources management. As a result, Indonesia fall on an ecological emergency or can be defined as a critical situation due to environmental damage. Abram (2016), the Reducing Emissions from 
Deforestation and Forest Degradation (REDD +) program in Malaysia aims to avoid forest conversion to alternative land-uses through financial incentives (p. 1). Another problem that occurs in oil palm expansion is the issue of child labor, indigenous peoples and marginalized local people. Even so, looking for palm oil substitute is not an easy job. Yew et. al (2016) indicates the palm oil industry has helped rural Malaysians get out of poverty and can raise the income hundreds of thousands of households. The contribution and the problems in management of palm oil commodities are as follows:
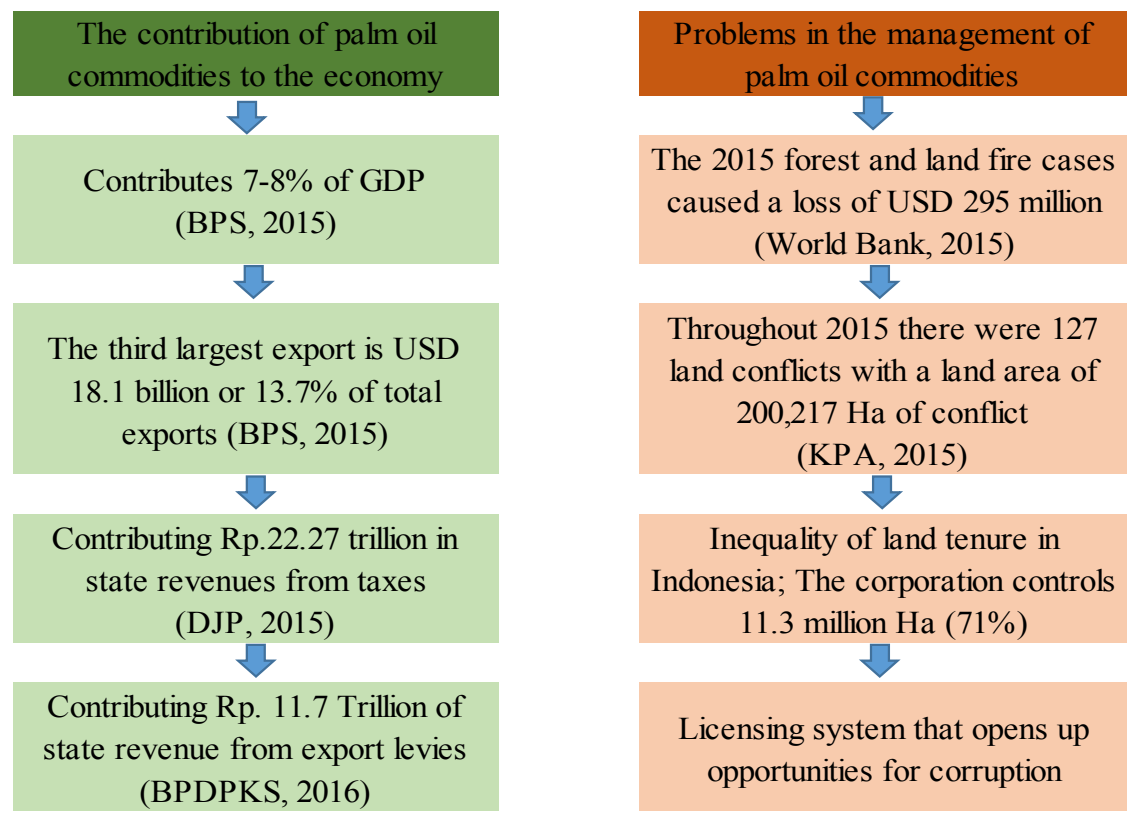

Figure 1. Contribution and Problems in Palm Oil Commodities Source: KPK Study (2016)

In Indonesia, palm oil plantations have triggered forest fires. About 19\% of land fires in 2015 occurred in palm oil plantations. Aryadi et. al (2017) stated that "forest and land fires in Indonesia have caused tremendous losses, both from the ecological, economic and socio-cultural aspects" (p. 222). On the other hand, palm oil also plays an important role in increasing the income of smallholders in oilproducing countries, especially in the two main countries of the world's palm oil producers, Malaysia and Indonesia. This proves that palm oil plantations have contributed to the development of rural areas. Malaysia and Indonesia produce around $90 \%$ of the world's palm oil. Therefore, discussing the solution to the problem of this industry cannot be done without involving Indonesia and Malaysia. Sustainable palm oil certification is expected to answer negative issues due to the adverse impacts of palm oil from Indonesia and Malaysia. Several palm oil certification models such as the Indonesian Sustainable Palm Oil (ISPO) and Roundtable for Sustainable Palm Oil (RSPO) could be the answer. Indonesia is starting to seriously address the problem of palm oil by making policies related to deforestation, loss of biodiversity and greenhouse gas emissions. "Today, consumers pressure is pushing companies toward deforestation-free of the palm oil sources" (Vijay et. al, 2016).

In order to assist the government to find sustainable solutions to economic development and solve problems related to climate change, the Financial Services Authority (FSA) works with the Ministry of Environment and is supported by the International Finance Corporation (IFC) and Sustainable Banking Network to launch the Sustainable Finance Roadmap in Indonesia. This roadmap introduces a comprehensive medium-term sustainable financial program (2015-2019) and long-term (2015-2024). The Roadmap is a reference for FSA and the financial services industry as well as other parties with an interest in supporting sustainable development. This roadmap details four principles of integrated sustainable finance to stimulate a competitive low-carbon economy transition and promote environmentally friendly investments in various business sectors. According to Ani and Fredy (2017), a sustainable finance roadmap was launched in the hope that it could become a leverage instrument in solving environmental problems and also increase the competitiveness of financial services companies 
in Indonesia. Laurence (2017) states that "it is important for Multilateral Development Banks (MDBs) to support the goals of the new global climate financial architecture" (p. 73). The Asian Development Bank (ADB) must review the policy architecture, strengthen accounting procedures, and coordinate efforts with other relevant parties. Mbengue and Moerloose (2017) indicate that "the MDBs have evolved from avoiding non-economic considerations, as required in most of their charters, to officially supporting sustainable development" (p. 389).

In 2016, supported by WWF-Indonesia and eight banks in Indonesia representing 46 percent of total national banking assets, FSA launched a pilot project "First Steps to become Sustainable Bank" to support banks achieving their targets in developing internal capacity for environmental and social risk management as stated in the Roadmap. The FSA also developed a Sustainable Palm Oil Financing Guidance in collaboration with WWF-Indonesia in early 2017 to facilitate financial services institutions in incorporating relevant Environmental and Social aspects into the palm oil sector policy. Based on the above phenomena, currently environmental and social issues are also important in business activities, where sustainable business principles must pay attention to the triple bottom line; profit, people and planet. Abdullah et. al (2017) said that "increasing the priority of the green economy by the company increases its sustainability in the economy" (p. 253).

The expansion of palm oil plantations cannot be separated from palm oil investments financed by banks and investors. As a financial intermediary, banks are exposed to the indirect impacts of their business and business practices, therefore banks need to be cautious in financing activity by conducting environmental, social and governance risk assessments. Therefore, banks need to be aware of their roles and responsibilities as investors and risk managers. Sharia Bank X also supported the Indonesian Sustainable Finance Initiative with another seven banks and joined the First Movers on Sustainable Banking (First Movers). Starting in 2015, eight First Movers member banks lead the First Steps to become Sustainable Bank program initiated by FSA and WWF-Indonesia, namely training, socialization, and implementation strategies for environmental and social governance risk management within the reach of each Bank. Sharia Bank X has collaborated in financing of the palm oil industry which has proven to contribute to the environment, to assist 10,000 smallholders over the past two years. Through initiation focused on sustainable finance, the Indonesian Sustainable Finance Initiative prioritizes the distribution of financing to qualified customers by mitigating risks related to environmental, social and governance aspects. Based on this, Sharia Bank X as a member of First Movers requires pre-screening tools before the financing process to customers in the palm oil industry according to environmental, social and governance aspects.

\section{THEORETICAL FRAMEWORK}

\section{Sustainable Finance.}

According to FSA (2014), "sustainable finance in Indonesia is defined as comprehensive support from the financial service industry to achieve sustainable development resulted from a harmonious relationship between economic, social and environmental interests" (p. 16). "Sustainable finance consists of dimensions: (1) Achieve industry, social and economic superiority in order to address the threats of global warming and mitigate other environmental and social issues; (2) Aims to encourage the shifting of the target towards a competitive low carbon economy; (3) Strategically promoting environmentally friendly investment in various business/ economic sectors; and (4) Supporting the principles of development in Indonesia as stated in the Medium Term Development Plan, namely the 4P (pro-growth, pro-jobs, pro-poor, and proenvironment)" (p. 16).

According to Deka (2015), "the principle of sustainable banks is a bank concerned with the social and environmental impacts of its investments and loans" (p. 13). This refers to initiatives taken by banks to encourage environmentally friendly investments, to provide priority financing to industries that have turned green or are trying to grow green. Thus, this can help to restore the natural environment. Green banking is beneficial, not only beneficial for banks and the economy but for its customers. This green banking initiative is mutually beneficial for banks, industry and the economy. Hajilou (2018) revealed that "sustainability is meeting the needs of the present generation without compromising the ability of future generations to meet their own needs" (p. 83). Bakar (2017) stated that "the majority of companies to invest in the recycling and reuse of materials, the environmental friendly technology, 
internal training on green economy, the rest of the electorate and the purchase and use of materials with less impact simply because they believe that investment to ensure the preservation of nature around" ( $p$. 139).

According to Kulsum and Huda (2018), "green financing and sustainable development have become a crucial aspect of today's financial sector" (p. 197). Green banking covers two aspects: greening the internal operations of the Bank and Financial Institutions and incorporating greening conditions into a green financing scheme. Green banking is not only a corporate social responsibility activity, but to keep the world livable without significant damage. Green banking that pays attention to social and environmental factors is also called ethical banking. The main objective of Green banking is to ensure the use of organizational resources that support the environment and society. Green banking as a concept is proactive and smart way of thinking with a vision for future sustainability of our only spaceshipthe earth (Sultana et. al, 2016). Haladu (2016), revealed "the fact that the banking industry is not a polluted or environmentally sensitive sector does not immune it from its consequences, because as members of community they equally owe a responsibility to society" (p. 586).

According to FSA (2014), "the goal of the sustainable finance program in Indonesia are to: (1) Improve the Financial Service Institutions (FSI)'s resilience and competitiveness to enable them to grow and develop in a sustainable manner. Resilience is associated with improved FSIs ability in risk management, while the competitiveness is associated with FSIs ability to innovate and produce environmentally friendly products/services; (2) Provide financing resources required by the public by using the pro-growth, pro-job, propoor and pro-environment Long Term Development Plan and Medium Term Development Plan as points of reference; (3) Contributes to the national commitment to address the global warming challenge by carrying out climate change mitigation and adaptation in business activities towards a competitive low carbon economy" (p. 16). Egwuma et. al (2016), indicating "the Nigerian government is helping smallholders by distributing oil press machines for sustainability and enhance the harvesting of Fresh Fruit Bunches" (p. 71). Nwaokocha et. al (2016), "in Nigeria, the use of the pressurized palm oil as fuel for cooking stove has numerous ecological, environmental and economic benefits" (p. 131). The design considers time efficiency, vapourization, combustion efficiency, raw material availability, user maintenance and security, atomization time and complexity. Akhtar (2015) revealed that "studies in the UK on Islamic Pension Financial Institutions have contributed to sustainable funding for global economic improvement" (p. 275).

According to FSA (2014), "the principles of a sustainable finance program in Indonesia include: (1) Risk Management Principle which integrates aspects of environmental and social protection in FSI's risk management to avoid, mitigate and minimize the negative impacts that may arise and promote increased value in the FSI's financing and operational activities, (2) Sustainable Priority Economic Sector Development Principle that is inclusive by increasing financing activities primarily in the industry, energy, agriculture (in the broadest sense), infrastructure and MSME sectors and at the same time striking a balance between the economic, environmental and social aspects; and provides financial services to the community who has limited or no access to financial services in the formal sector, (3) Environmental and Social Governance and Reporting Principle by implementing robust and transparent environmental and social governance practices in the Financial Service Institution's operational activities as well as ensuring that the same environmental and social governance practices are implemented by the FSI's clients; and periodically reports the progress of FSIs in implementing the principles of sustainable finance to the public, (4) Capacity Enhancement and Collaborative Partnership Principle by developing human resource, information technology and the operational capacity of each relevant LSI in implementing the principles of sustainable finance; and establishes cooperation between the FSIs, regulator, government and leverages on the partnership with domestic and international institutions to advance progress in the area of sustainable finance" (p. 18). Environment, Social and Governance are the terminology and concepts that were first proposed by the "Who Cares Wins" initiative of the UN Global Compact which aims to focus the majority of investors and financial analysts on the principles of financial statements related to Environmental, Social and Governance.

According to FSA (2014), "strategic activities to implement sustainable finance in Indonesia comprise of three focus area as follows: (1) Increase supply of environmentally friendly Financing, (2) Increase demand of environmentally friendly financing products, (3) Increase oversight and coordination of sustainable finance implementation. The above strategic activities will be implemented gradually in the Medium Term and Long Term, as described below: (1) Medium Term (2015-2019), 
the strengthening of sustainable finance will focus on the basic regulatory framework and reporting system, increase understanding, knowledge and competence of the human resources in the financial services industry, provision of incentives and coordination with related agencies; (2) Long term (20202024), the activities will focus on integrated risk management, corporate governance, bank rating, and the development of an integrated sustainable finance information system" (p. 19). Siswanti et. al (2017), stated "corporate governance has a significant impact on Islamic financial performance" (p. 316).

According to FSA (2014), "a number of expected accomplishments in the implementation of sustainable finance in the medium term and long term are as follows: (1) In the Medium Term (20152019), the basic regulatory framework and reporting system are expected to be established and running well. The understanding, knowledge and competence on sustainable finance of the human resources in the financial services industry are expected to increase and the provision of incentives and coordination with related agencies have been well executed and carried out regularly. A system to monitor the increase in financing volume of priority economic sectors that adapt sustainable finance principles is expected to be established, (2) In the Long Term (2020-2024), FSIs are expected to have integrated environmental and social aspects in its risk management and corporate governance, and provide regular progress reports on sustainable finance implementation to the public. An integrated information system with relevant institutions to support the implementation of sustainable finance has been established and running well. The sustainable finance program is also expected to contribute to reducing the national greenhouse gas emission" (p. 19-20).

\section{METHOD}

In this study, researchers used a qualitative research approach. Some key words in qualitative research, namely process, understanding, complexity, interaction and humans. The process of conducting research is an emphasis in qualitative research. Therefore, in carrying out research, researchers focus more on the process than the end result. The process requires time and conditions that change, so that the definition of this research will have an impact on research design and ways of implementing it that are changing or flexible. Researchers conducted research using qualitative research with a descriptive approach, which was carried out with participation, Focus Group Discussion (FGD) and literature study as a technique in data collection. Research with qualitative design is considered appropriate to produce explicit explanations of the processes experienced by various research informants. Qualitative research is also concerned with finding a truth about phenomena in the context in which research is carried out (ideographic).

The number of participants determined in this study using purposive sampling technique, which is a technique that uses consideration and intuition to select the best people and groups to learn or in this case provide accurate information. In this study, in addition to taking participants from Sharia Bank $\mathrm{X}$, the researchers also included participants from external Sharia Bank X consisting of Regulators, Non-Governmental Organizations (NGOs) and practitioners in the field of palm oil industry. The data collected in this study was obtained from primary data and secondary data. Primary data was obtained from the results of the Focus Group Discussion (FGD) to the participants. While secondary data is obtained from data from Regulators, NGOs, practitioners and other third parties. Internal data obtained in the form of annual company reports, Minutes of Meeting (MoM), data files, etc., while external data obtained in the form of Indonesian Sharia Banking Snapshot, Sustainable Finance Roadmap, Implementation Guidance and other related documents. After the data is collected, then classified into data that is expressed in the form of words or symbols, which is an attempt to systematically search and organize. Wagemans et. al (2018) mention that "NGOs can become media providers of environmental, social and governance data" (p. 310). Participation records and Focus Group Discussions (FGD) were conducted to improve understanding of the case under study and present findings to others.

The Sustainable Finance Roadmap set by the FSA is shown in Figure 2. Implementation of the Sustainable Finance Roadmap at Sharia Bank X is carried out in accordance with POJK No. 51 of 2017 concerning Implementation of Sustainable Finance for Financial Service Institutions, Issuers, and Public Companies, so that the following research frameworks are obtained in 


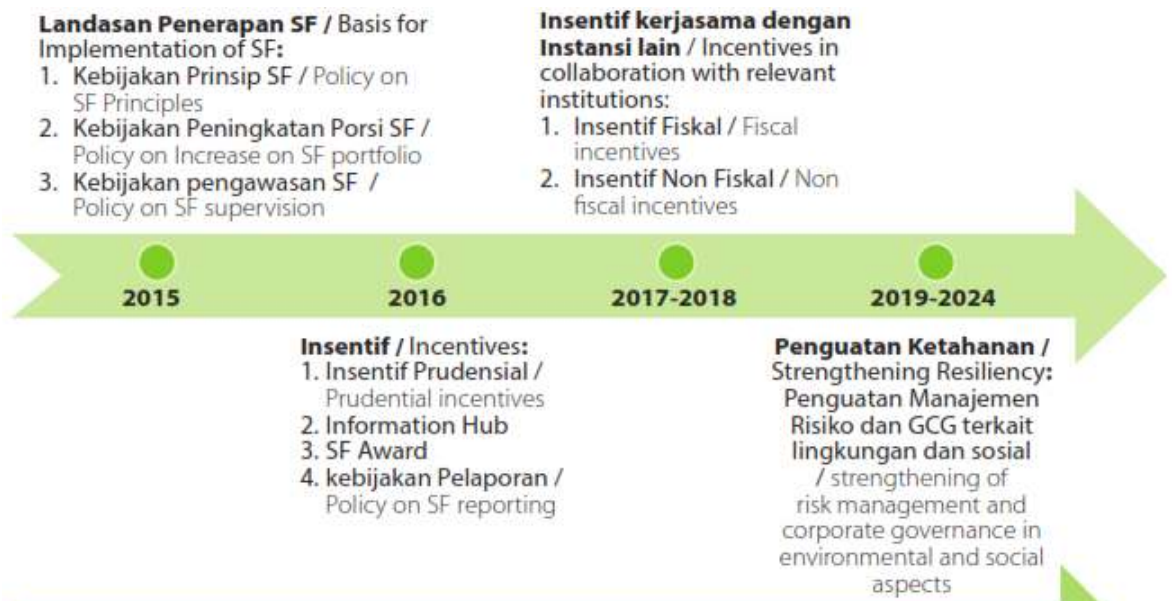

Insentif kerjasama dengan

Instansi lain / Incentives in

collaboration with relevant

Policy on Incred

. Kebijakan pengawasan SF /

Policy on SF supervision

Insentif Non Fiskal / Non

fiscal incentives

\section{5-2019: \\ Kampanye/Campaign, Training Analis LH/Environmental Analyst Trainings, Pengembangan/ \\ development of green product, Green Bond and Green Index, akses LK terhadap/FSIs access to \\ Global Public Funds, Koordinasi kebijakan SF/ Coordination on SF policy}

Figure 2. Sustainable Finance Roadmap

Source: FSA (2014)

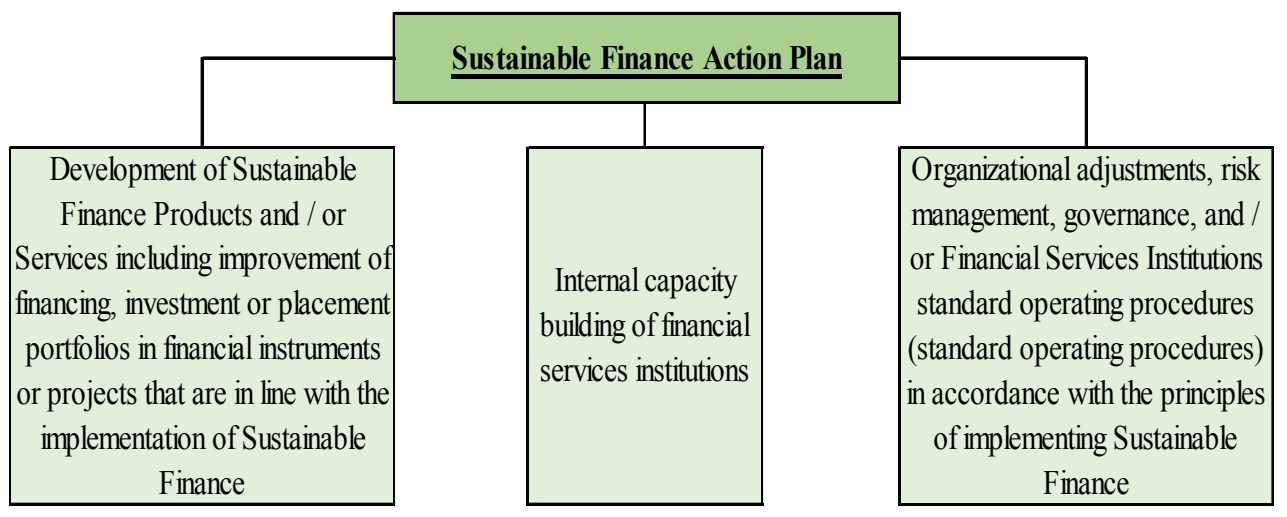

Figure 3. Research Framework

Source: Processed Data (2018)

In the first stage of data analysis, observations and Focus Group Discussions will be conducted to participants in the development of sustainable financial products and/or services including an increase in financing, investment or placement portfolios in financial instruments or projects that are in line with the implementation of Sustainable Finance. Accordingly the financial products and/or services that are in line with the implementation of Sustainable Finance are; financing of renewable energy projects (financing of power plants sourced from hydropower, geothermal power, wind power, solar power, biogas power, biomass and renewable energy sources others set by the government), energy efficiency (financing replacement of air conditioner chillers, financing of replacing energy-efficient textile machines, building renovations to improve energy efficiency by replacing energy-saving lamps), sustainable agriculture, sustainable fisheries (fishing activities without trawling nets and explosives), green building projects (financing the construction of environmentally friendly buildings), and ecofriendly tourism (tours to improve biodiversity, fauna conservation and other natural resources). The second stage is observation and Focus Group Discussion to participants in terms of internal capacity building of Financial Services Institutions. The next step is organizational adjustment, risk management, governance, and/or Financial Services Institutions standard operating procedures in accordance with 
the principles of implementing Sustainable Finance. Sukirman (2018) stated that "the Sustainable Financing Model for Renewable Energy would complement regular credit rating models by yielding qualitative and quantitative information that would lead to improved decision-making" (p. 2).

\section{RESULT AND DISCUSSION}

In the first stage of data analysis, observations and Focus Group Discussions will be conducted to participants in the development of sustainable financial products and/or services including an increase in financing, investment or placement portfolios in financial instruments or projects that are in line with the implementation of Sustainable Finance. Accordingly the financial products and/or services that are in line with the implementation of Sustainable Finance are; financing of renewable energy projects (financing of power plants sourced from hydropower, geothermal power, wind power, solar power, biogas power, biomass and renewable energy sources others set by the government), energy efficiency (financing replacement of air conditioner chillers, financing of replacing energy-efficient textile machines, building renovations to improve energy efficiency by replacing energy-saving lamps), sustainable agriculture, sustainable fisheries (fishing activities without trawling nets and explosives), green building projects (financing the construction of environmentally friendly buildings), and ecofriendly tourism (tours to improve biodiversity, fauna conservation and other natural resources). Based on the observation and Focus Group Discussion, it was found that at the end of 2016, Sharia Bank X had a palm oil financing program with a partnership scheme between Bank, Smallholders and Nucleus (Guarantor Company). Sharia Bank X starts to finance smallholders for groups that already have Roundtable on Sustainable Palm Oil (RSPO) certification or Indonesian Sustainable Palm Oil (ISPO) and concern to the aspects of Environment, Social and Governance. The financing of palm oil plantations up to December 2017 reached IDR 787 billion consisting of 24 cooperatives, 6,261 smallholders with an area of 11,963 hectares spread across 9 provinces and 11 districts in Indonesia.

The second stage is observation and Focus Group Discussion to participants in terms of internal capacity building of Financial Services Institutions. Based on observations and Focus Group Discussion, information was obtained that from 2015 to 2018, Sharia Bank X had held several seminars, workshops, focus group discussions and training that presented by Regulators, Non-Governmental Organizations, industrial players and other related parties in order to increase and develop the internal capacity of Sharia Bank X.

The next step is organizational adjustment, risk management, governance, and/or Financial Services Institutions standard operating procedures in accordance with the principles of implementing Sustainable Finance. Based on observations and Focus Group Discussion, information was obtained that Sharia Bank X had made organizational adjustments and made policies regarding Sustainable Finance. Organizational adjustment is done by forming a "Plasma Specialist Unit" that focuses on financing smallholders assisted by corporate companies. This formation was carried out by recruiting human resources from internal and external experts in the field of palm oil. In addition to reorganizing, Sharia Bank X also adjusts financing procedures in the palm oil business, one of which is by applying the acceptance criteria in the form of Environmental, Social and Governance checklists in order to screen customers before financing process started. Based on observations and Focus Group Discussion, the results of the ESG checklist were obtained as follows:

Table 1. Environmental, Social and Governance Checklist (ESG).

\begin{tabular}{clll}
\hline $\begin{array}{c}\text { Assessment } \\
\text { Aspects }\end{array}$ & \multicolumn{1}{c}{ Questions } & Supporting Document \\
\hline $\begin{array}{c}\text { Environment } \\
\text { Sub-General }\end{array}$ & $\begin{array}{l}\text { Does the company have proof of licensing AMDAL, RKL-RPL Report to } \\
\text { documents and legality in environmental related parties } \\
\text { management, namely AMDAL/UKL-UPL } \\
\text { documents and Environmental Permits? }\end{array}$ & \\
& $\begin{array}{l}\text { Is there a record/report on the implementation of AMDAL, RKL-RPL Report to } \\
\text { UKL-UPL/AMDAL, namely the RKL-RPL Report related parties } \\
\text { to the relevant parties? }\end{array}$
\end{tabular}




\begin{tabular}{cll}
\hline $\begin{array}{c}\text { Assessment } \\
\text { Aspects }\end{array}$ & \multicolumn{1}{c}{ Questions } & \multicolumn{1}{c}{ Supporting Document } \\
\hline & $\begin{array}{l}\text { Are there prevention SOPs as well as human SOP / GMP or statement of } \\
\text { resources, facilities and infrastructure for emergency } \\
\text { response systems for fire prevention? }\end{array}$ &
\end{tabular}

SubPlantation
If planting is on peat land, have companies noticed the characteristics of the land and the applicable provisions?

Does the company use chemicals properly and not excessive for handling weeds, pests and diseases?

Do customers open new palm oil land,

a. without burning

b. by looking at the Indicative Map of Postponement of Granting New Permits

c. by looking at the Peat restoration map

d. by considering the High Conservation Value area plan for protecting conservation areas (rare and protected flora and fauna), reducing the impact of damage to land and water, the source of community life, and special socio-culture for the community.

Does the company have a strategy to deal with climate change that can be measured, stated and determined to reduce GHG (Green House Gas) emissions?

Are there overall operational operational SOPs using the concept of Good Agricultural Practices (GAP) and Best Management Practices (BMP) on oil palm plantations?

Sub-Palm Oil Does the Processing Facility on peat land have a Mill building/construction plan that is in accordance with the characteristics of the land and the applicable provisions?

Has the processing facility factory waste been managed in accordance with the applicable provisions?

Is there a wastewater management installation?

Are there SOPs for the management of B3 waste, liquid, solid and gas waste?

Is there a permit from the relevant parties for the disposal of good waste to water/sea/river bodies?
See the peat moratorium regulations, the peat map and the Peat restoration map. Look at the BRG/KLHK website. http://brg.go.id/tag/perusahaan/ http://brg.go.id/peta-restorasi/

AMDAL, List of Chemicals used (not containing Paraquat), in accordance with Permentan $1 / 2007$ and the Pesticide Commission Book

Site Visit Call Report, SOP for land clearing without burning, fire history.

Work plan for plantation development and processing units, HCV assessment, Reference for HCV consultants: Aksenta or Daemeter (Large Scale), Bioref IPB and Sonokeling IPB (Small Scale)

Inventory of chemical use, GHG reduction mitigation plan, descriptive documentation/story of land restoration

SOP/GMP, Site Visit Call Report

Peat Map, AMDAL

Data of chemicals used, results of non-waste disposal tests, RKL \& RPL Reports, and results of quality tests

Map/layout of IPAL and its coordinates

SOP/GMP, Permit from BLHD, Permit for temporary storage of B3 waste

Permission from BLHD and local regulation 


\begin{tabular}{cl}
\hline $\begin{array}{c}\text { Assessment } \\
\text { Aspects }\end{array}$ & \multicolumn{1}{c}{ Questions } \\
\hline $\begin{array}{c}\text { Social } \\
\text { Sub-General }\end{array}$ & $\begin{array}{l}\text { Do regular consultations/open communication } \\
\text { between stakeholders and the surrounding } \\
\text { community be carried out regularly? }\end{array}$ \\
& $\begin{array}{l}\text { Are there procedures/SOPs and/or documentary } \\
\text { evidence of issues related to the company's existence } \\
\text { (overlapping mining operations, community land }\end{array}$ \\
& $\begin{array}{l}\text { occupation, waste management from all plantation } \\
\text { operations and processing facilities/factories, land } \\
\text { management)? }\end{array}$ \\
& $\begin{array}{l}\text { Does the company employ employees according to } \\
\text { the age allowed (not underage children) and apply } \\
\text { fair treatment to all employees } \\
\text { discrimination)? }\end{array}$ \\
& $\begin{array}{l}\text { Does the company have a program as an effort to } \\
\text { improve the welfare of the surrounding/indigenous } \\
\text { population? }\end{array}$
\end{tabular}

Sub- Does the company have evidence of implementing Plantation best practices and following the applicable provisions regarding employment on plantation land?

Does the company make the recruitment of workers from the local community a top priority?

Are there any positive impacts of the plantation in increasing the income of the local community?

If land ownership comes from an acquisition, does the land owner/land user have a complete legal document on the acquired land (for example: legality of land ownership and planting license) and social environmental permit documents (eg. documentation from the community)?

Sub-Palm Oil Do the surrounding communities accept the Mill existence of processing facilities?

Does the Processing Facility have a positive impact on increasing local income?

Government Sub-General

Does the company have a vision and mission/work plan/work program/guide that concern to the environment in its business activities and has a longterm plan for it?

Does the company have documentary evidence of all plantation operations, both plantations and processing/factory facilities, namely Principle Licenses, Decrees on Forest Area Disposal and Timber Utilization Permits?
Minutes/Reports related to the consultation or communication, Policies and SOPs, and CSR reports

Research through the Internet, Call Report Visit

Policies and SOPs, Call Report Site Visit, Research via the internet

Policies and SOPs, as well as CSR reports

Research through the Internet

Site Visit Call Report, Employee Data (If possible)

Site Visit Call Report

Business legality and plantation business permits

Site Visit Call Report

Site Visit Call Report

Company Profile

Licensing Legality 


\begin{tabular}{|c|c|c|}
\hline $\begin{array}{l}\text { Assessment } \\
\text { Aspects }\end{array}$ & Questions & Supporting Document \\
\hline & $\begin{array}{l}\text { Has the company's operations never been affected by } \\
\text { complaints from shareholders, the media, or non- } \\
\text { governmental organizations (NGOs)/NGOs related } \\
\text { to environmental and social issues? }\end{array}$ & Site Visit Call Report \\
\hline & $\begin{array}{l}\text { Does the company implement a safety, occupational } \\
\text { health management system with accident insurance, } \\
\text { infrastructure and documentation? }\end{array}$ & $\begin{array}{l}\text { SOP/GMP or statement of } \\
\text { availability of SOP/GMP }\end{array}$ \\
\hline & $\begin{array}{l}\text { Has the experience of the management and/or } \\
\text { shareholders been above } 10 \text { years? }\end{array}$ & $\begin{array}{l}\text { CV of Management and Company } \\
\text { Shareholders }\end{array}$ \\
\hline & Are trade unions formed? & Site Visit Call Report \\
\hline $\begin{array}{l}\text { Sub- } \\
\text { Plantation }\end{array}$ & $\begin{array}{l}\text { Is the company at least included in the good land } \\
\text { class category (class } \\
\text { PERMENTAN? according to the }\end{array}$ & Location Permit and Call Report \\
\hline \multirow[t]{3}{*}{$\begin{array}{l}\text { Sub-Palm Oil } \\
\text { Mill }\end{array}$} & $\begin{array}{l}\text { Does the Processing Facility have a supply of FFB } \\
\text { that comes from their own plant? }\end{array}$ & FFB production report \\
\hline & $\begin{array}{l}\text { Does the Processing Facility get FFB supply from } \\
\text { internal }>20 \% \text { ? }\end{array}$ & Report on purchasing FFB \\
\hline & $\begin{array}{l}\text { Are there adequate infrastructure (road access and } \\
\text { other support)? }\end{array}$ & Call Report/Site Visit \\
\hline
\end{tabular}

The ESG checklist is filled in by the Business Team and the Financing Risk Team, where the checklist is filled in according to the prospective customer's business line, for example Plantation only, Processing Facilities only or Plantation and Processing Facilities. The assessment form produces scoring and there is a conclusion "Comply" or "Near to Comply". If the results obtained are "Near to Comply", then the Business Unit must provide an explanation and proposed mitigation of the risks that may arise in the proposal for financing proposals to be considered by the financing committee in making decisions.

\section{CONCLUSION}

Based on the research that has been carried out, in terms of the development of sustainable financial products and/or services including an increase in financing portfolio, investment or placement in financial instruments or projects in line with the implementation of Sustainable Finance, it is known that at the end of 2016, Sharia Bank X already has a financing program palm oil with a partnership scheme. Sharia Bank X finances smallholders for groups that already have Roundtable on Sustainable Palm Oil (RSPO) certification or Indonesian Sustainable Palm Oil (ISPO) and pay attention to Environmental, Social and Governance aspects. Financing of palm oil plantations with a partnership scheme until December 2017 reached IDR 787 billion consisting of 24 cooperatives, 6,261 smallholders with an area of 11,963 hectares spread across 9 provinces and 11 districts in Indonesia.

Based on the results of observations and Focus Group Discussions, in terms of internal capacity building of Financial Services Institutions, information was obtained that from 2015 to 2018, Sharia Bank X had held several seminars, workshops, focus group discussions and training that presented persons from the Regulator, Non Governmental Organization (NGO), industrial players and other related parties in the framework of developing Sharia Bank X internal capacity in relation to Sustainable Finance.

In making organizational adjustments, risk management, governance, and / or standards of operational procedures (standard operating procedures) of the Financial Services Institutions in accordance with the principles of the implementation of Sustainable Finance, information was obtained that Sharia Bank X has made organizational adjustments and made policies regarding Sustainable 
Finance. Organizational adjustment is done by forming a "Plasma Specialist Unit" that focuses on financing smallholders assisted by corporate companies. This formation was carried out by recruiting human resources from internal and external experts in the field of palm oil. In addition to reorganizing, Sharia Bank X also adjusts financing procedures in the palm oil business, one of which is by applying the acceptance criteria in the form of Environmental, Social and Governance checklists in order to screen customers before financing process started.

Based on the results of research that has been conducted, suggestions for practical aspects, Sharia Bank X as a member of the First Mover Sustainable Bank is carrying out a Sustainable Finance Action Plan, Sharia Bank X is expected to follow the sustainable financial roadmap set by the FSA as the regulator in accordance with timeline that has been set. While suggestions for academic aspects include; further research is recommended to be carried out in a wider scope, for example the application of Sustainable Finance to all members of the First Mover Bank appointed by the FSA as the Regulator. Furthermore, research is also recommended to explore other sustainable products, such as financing for renewable energy projects (financing power plants sourced from hydropower, geothermal power, wind power, solar power, biogas, biomass and other renewable energy sources that set by the government), energy efficiency (financing replacement of air conditioner chillers, financing of replacing energyefficient textile machines, building renovations to improve energy efficiency by replacing energysaving lamps), sustainable agriculture, sustainable fisheries (fishing activities without trawling and explosives), green building projects (financing the construction of environmentally buildings), and environmentally tourism (tours to improve biodiversity, fauna conservation, and other natural resources). Sharia Bank X also adjusts financing procedures in the palm oil business sector, one of which is by applying acceptance criteria in the case of Environmental, Social and Governance (ESG) checklists in order to screen customers before financing process started, further research is needed to measures the effectiveness of the Environment, Social and Governance checklist (ESG).

\section{REFERENCES}

Abdullah, Hussin A., et. al. (2017). The Current State of Malaysia's Journey towards a Green Economy: The Perceptions of the Companies on Environmental Efficiency and Sustainability, International Journal of Energy Economics and Policy, 253-258, volume 7 No. 1. Retrieved from www.econjournals.com

Abram, Nicola K. A. et. al. (2016). Identifying Where REDD+ Financially Out Competes Oil Palm in Floodplain Landscapes Using a Fine-Scale Approach, 1-23. Retrieved from 10.1371/journal.pone.0156481

Akhtar, Zia,. A. (2015). Auto Enrolment, Pension Trusts and Ethical Finance: Banks and Regulators Have an Increasing Role in Promoting Shariah Finance. International Journal of Disclosure and Governance, volume 12 No. 12, 275-283. Retrieved from 10.1057/jdg.2015.7

Ani, Salis Musta. A, \& Fredy, Hotman. B. (2017). Mekanisme Governance dan Pengungkapan Sustainable finance: untuk melihat tingkat Kesiapan Penerapan Sustainable Finance pada Perusahaan Jasa Keuangan Terdaftar di BEI. Jurnal Akuntansi, volume XXI No. 03, 437-447. Retrieved from dosen.univpancasila.ac.id/

Aryadi, Mahrus. A., Satriadi, Trisnu B., Syam'ani C. (2017). Kecenderungan Kebakaran Hutan dan Lahan dan Alternatif Pengendalian Berbasis Kemitraan di PT. Inhutani II Kotabaru, Jurnal Hutan Tropis, 222-235, volume 5 No. 3. Retrieved from https://search.proquest.com/

Bakar, Nor'Aznin Abu. A., et. al. (2017). Green Economy: Evaluation of Malaysian Company Environmental Sustainability, International Journal of Energy Economics and Policy, volume 7 (2), 139-143. Retrieved from www.econjournals.com 
Deka, Gobinda. A. (2015). Green Banking Practices: A Study on Environmental Strategies of Banks with Special Reference to State Bank of India, Indian Journal of Commerce \& Management Studies, volume VI No. 3, 11-19. Retrieved from www.scholarshub.net

Egwuma, Henry. A., et. al. (2016). A Model for The Palm Oil Market in Nigeria: An Econometrics Approach. International Journal of Food and Agricultural Economics, volume 4 No. 2, 69-85. Retrieved from https://search.proquest.com/

Hajilou, Mahran. A., et. al. (2018). Financial Sustainability of Municipalities and Local Governments in Small-Sized Cities; a Case of Shabestar Municipality, Journal of Local Self-Government, volume 16 No. 1, 77-106. Retrieved from https://doi.org/10.4335/16.1.77-106

Haladu, Alhassan. A. (2016). Assessing the Relationship between Banking Capitalization and Sustainable Development in Nigeria. International Journal of Management Research \& Review, volume 6 No. 5, 586-596. Retrieved from www.ijmrr.com

Info Publik, Luas Kawasan Hutan Indonesia 125,9 Juta Hektare, http://infopublik.id/read/259865/luaskawasan-hutan-indonesia-1259-juta-hektare-.html

Kulsum, Rabeya A., Sadrul, Huda B. (2018). Re-Thinking About the Green Banking Model in the Context of Bangladesh, The Journal of Developing Areas, 197-214, volume 52 No. 2 Retrieved from http://www.unepfi.org/

Kumparan, Kontribusi Sektor Pertanian dan Target Indonesia sebagai Lumbung Pangan Dunia 2045, https://kumparan.com/citra-vita-yuningtyas/kontribusi-sektor-pertanian-dan-target-indonesiasebagai-lumbung-pangan-dunia-2045

Laurence, Delina A. (2017). Multilateral Development Banking in a Fragmented Climate System: Shifting Priorities in Energy Finance at the Asian Development Bank, Journal of International Environmental Agreements : Politics, Law and Economics, 73-88. Retrieved from http://dx.doi.org/10.1007/s10784-016-9344-7

Layeni, Abayomi. A., Nwaokocha, Collins. B., (2016). Design and Fabrication of a Palm Oil Pressure Stove, International Journal of Energy, Environment, and Economics, volume 24 No. 1, 131146. Retrieved from https://search.proquest.com/

Mbengue, Makane Moïse A. \& Moerloose, Stéphanie de B. (2017). Multilateral Development Banks and Sustainable Development: On Emulation, Fragmentation and a Common Law of Sustainable Development, Law and Development Review. Retrieved from 389-424. 10.1515/ldr-2017-0026

Mongabay, Label Berkelanjutan Jawaban Atasi Masalah Sawit, Benarkah?, http://www.mongabay.co.id/2018/05/10/label-berkelanjutan-jawaban-atasi-masalah-sawitbenarkah/

Peraturan Otoritas Jasa Keuangan (POJK) No. 51 /POJK.03/2017 tentang Penerapan Keuangan Berkelanjutan Bagi Lembaga Jasa Keuangan, Emiten, dan Perusahaan Publik.

Pratiwi, Rahajeng A., et. al. (2014). Roadmap Keuangan Berkelanjutan di Indonesia (pages 20). Jakarta: Otoritas Jasa Keuangan.

Siswanti, Indra A., et. al. (2017). The Impact of Islamic Corporate Governance, Islamic Intellectual Capital and Islamic Financial Performance on Sustainable Business Islamic Banks, International Journal of Economics and Financial Issues, 316-323, volume 7 No. 4. Retrieved from www.econjournals.com 
Stampe, Jeanne A., et. al. (2015). Integrasi Lingkungan Sosial dan Tata Kelola bagi Bank (pages 13). Jakarta: Otoritas Jasa Keuangan.

Sukirman, Y. A., A., et. al. (2018). Developing a Green Lending Model for Renewable Energy Project (Case Study Electricity from Biogas Fuel at Palm Oil Industry), 1-7. Retrieved from $10.1088 / 1755-1315 / 131 / 1 / 012037$

Sultana, Roushan Ara, A, Shahidullah, Mohammad B., Mohammad Saleh, Jahur. C. (2016). Green Banking Practices of Some Commercial Banks in Bangladesh with Reference to the Guidelines of Bangladesh Bank, International Journal of Arts \& Sciences, 145-159. Retrieved from https://search.proquest.com/

TuK Indonesia, Penundaan dan Penjadwalan Ulang Diskusi "Kelapa Sawit Indonesia: Peran OJK, Bank dan Investor, http://www.tuk.or.id/penundaan-dan-penjadwalan-ulang-diskusi-kelapa-sawitindonesia-peran-ojk-bank-dan-investor/

Vijay, Varsha A., et. al. (2016). The Impacts of Oil Palm on Recent Deforestation and Biodiversity Loss. Retrieved from 10.1371/journal.pone.0159668

Wagemans, Frank A J. A., \& Mol, Arthur PJ B. (2018). Engagement on ESG issues by Dutch pension funds: is it reaching its full potential? Journal of Sustainable Finance \& Investment, volume 8 No. 4, 301-322. Retrieved from https://doi.org/10.1080/20430795.2018.1485379

YEW, Vivien W. C. A., et. al. (2016). The Sustainability of Oil Palm Industry in Malaysia: A Comprehensive Review, International Journal of Economic Perspectives, 305-310, volume 10 No. 4. Retrieved from http://www.econ-society.org 